Proceedings of the Annual Conference of the Agricultural Extension Society of Nigeria

Number: Twenty-Second Annual Conference

Theme: Mainstreaming Entrepreneurship in Agricultural Extension Practice in Nigeria

Date: $23^{\text {rd }}-26^{\text {th }}$ April, 2017. Venue: University of Port Harcourt, River State, Nigeria

ISSN: 1595 - 1421.http://aesonnigeria.org/ConfProc . Email: editorinchief@aesonnigeria.org

\title{
Effects of Socio-Economic Characteristics on the Profitability of Poultry Production among Poultry Farmers in Kaduna State \\ https://dx.doi.org/10.4314/jae.v22i1.19S
}

Suleiman, R. ${ }^{1}$, Mahmud, A. M. ${ }^{1,}$ Oladimeji, Y.U. ${ }^{1}$, Olanrewaju, T.O. ${ }^{2}$, Ojeleye.O. $A^{1}$

${ }^{1}$ Department of Agricultural Economics and Rural Sociology, Institute for Agricultural Research. Ahmadu Bello University, P.M.B 44, Zaria, Kaduna State, Nigeria Email: rabiu.suleiman@yahoo.com,Phone: 08033576713

2Department of Agricultural Engineering and Irrigation, National Agricultural Extension and Research Liaison Services, Ahmadu Bello University, P.M.B 44, Zaria, Kaduna State, Nigeria

\begin{abstract}
The study examined the effects of socio-economic characteristics on the profitability of poultry farmers in Kaduna State, Nigeria. Data were collected using questionnaire from 160 poultry farmers. One LGA each was randomly selected from the four agricultural zones in Kaduna State; Birnin-Gwari Zone, Maigana Zone, Lere Zone and Samaru-Kataf zone. The data collected were analyzed using descriptive statistics, multiple regression and gross margin models. Results revealed that the majority $(71.3 \%)$ of the respondents were male, $58.7 \%$ were married, $47.5 \%$ were within the age of 31-40 years and 98\% of the respondents were educated with different educational qualifications. The multiple regression result with $R^{2}$ of 0.658 indicated that $65.8 \%$ of the factors affecting profitability were accounted for by the independent variables. Farming experience and access to credit were found to be positive and statistically significant at $1 \%$ level of significance while household size had inverse relationship in poultry production profitability in the study area. The constraints faced by the farmers include high cost of feeds and vaccination, disease incidence, high mortality rate, lack of credit and low marketing. Recommendations made include provision of market for products, regulation of prices of inputs and provision of adequate extension services to the farmers in the study area.
\end{abstract}

Keywords: Effects, poultry, production

\section{Introduction}

The Livestock sector is an important component of the Nigeria agricultural economy that provides animal protein to the populace as well as employment for a considerable percentage of the population (Oyesola and Olujide, 2000). The most common livestock production practiced in rural areas of Nigeria is poultry keeping 


\section{Proceedings of the Annual Conference of the Agricultural Extension Society of Nigeria \\ Number: Twenty-Second Annual Conference \\ Theme: Mainstreaming Entrepreneurship in Agricultural Extension Practice in Nigeria \\ Date: $23^{\text {rd }}-26^{\text {th }}$ April, 2017. Venue: University of Port Harcourt, River State, Nigeria \\ ISSN: 1595 - 1421.http://aesonnigeria.org/ConfProc . Email: editorinchief@aesonnigeria.org}

(Okoli, Anyaegbunam, Etuk, Uchegbu, and Udedibie, 2004). Livestock industry in Nigeria is ridden with myriad of problems, which have resulted to a gross shortage of meat and other animal products (Nworgu, 2002). However, according to Kazybayeva, Otte, and Roland-Holst (2006), Food and Agriculture Organization (FAO, 2007), Noula (2011), Jane, Odo, Asadu, and Enwelu, (2012) poultry has become a popular industry for the small holders that have great contribution to the economy of Nigeria. Poultry is one of the major sources of meat protein apart from sheep, cows and goats. It is also a major source of income to farmers who are involved in poultry production for commercial purposes. The poultry sub-sector is the most commercialized of all of Nigeria's agricultural sub-sectors.

The livestock sector is vital to the socio-economic development of Nigeria. It contributes about $9-10 \%$ of agricultural GDP (FAO, 2006). Moreover, Nigeria's chicken population is about 150.682 million (UNDP, 2006) of which $25 \%$ are commercially farmed, $15 \%$ semi-commercially, and $60 \%$ in backyards. Consequently, livestock represents an important source of high quality animal protein, providing about 36.5 per cent of the total protein intake of Nigerians.

The United Nations Food and Agriculture Organization (FAO) estimated poultry population in Nigeria to be in the range of $175,000,000$ in 1987 and 200,000,000 in 2002. These figures reveal a very slow growth rate of nation's poultry industry. The imports of chilled and frozen poultry meats into Nigeria for the years 2000 to 2005 shows that the total import of poultry products over the five-year period is $11,045,522$ $\mathrm{kg}$. The import figures declined from $421,569 \mathrm{~kg}$ in 2003 to $2,235 \mathrm{~kg}$ in 2005 , due to review of import policy which is unfavourable for local production. Thus, indicating a declining contribution of poultry imports to poultry products consumption in Nigeria (National Bureau of Statistics, NBS, 2006).

Despite these positive aspects, poultry production has not been keeping pace with rapidly increasing domestic consumption. The domestic shortfall in Nigeria is estimated at 25,000 Metric Ton (MT) per annum (Rotschild, 2002). About ten (10) percent of Nigerian populations are engaged in poultry production, mostly on subsistence and small or medium-sized farms (Okonkwo and Akubuo, 2001). According to the United State Department of Agriculture (USDA, 2013) report, the Nigerian poultry industry is estimated at N80 billion and is comprised of approximately 165 million birds, which produced 650,000 MT of eggs and 290,000 MT of poultry meat in 2015. Nigeria's egg production is the largest in Africa (with South Africa second which has the next largest at 540,000 MT of eggs) and it has the $2^{\text {nd }}$ largest chicken population after South Africa's 200 million birds (source). 


\section{Proceedings of the Annual Conference of the Agricultural Extension Society of Nigeria \\ Number: Twenty-Second Annual Conference \\ Theme: Mainstreaming Entrepreneurship in Agricultural Extension Practice in Nigeria \\ Date: $23^{\text {rd }}-26^{\text {th }}$ April, 2017. Venue: University of Port Harcourt, River State, Nigeria \\ ISSN: 1595 - 1421.http://aesonnigeria.org/ConfProc . Email: editorinchief@aesonnigeria.org}

According to the FAO (2014), growing populations, economies and incomes are fuelling on ongoing trend towards high consumption of animal protein in developing countries including Nigeria. Nigeria like any other developing countries, suffers from protein deficiency due to rapid growth, low productivity in the agricultural sector, rural-urban migration and decline in productivity of the livestock subsector (Abubakar, 2000). This shows how important poultry farming is in Nigeria. Poultry is one of the livestock productions that yield a lot of output within a short payback period. However, in recent years this is not as it used to be. Findings has revealed that limited finance, lack of experience, high cost of input and labor with unfriendly government policy had adversely affected the overall performance of poultry farmers (Akeeb 1997; Agbato, 1997).

The main objective of the study was to determine the effect of socio-economic characteristics on the profitability of poultry production to poultry farmers.

The specific objectives were to:

i. describe the socio-economic characteristics of poultry farmers.

ii. determine the profitability of poultry production to farmers.

iii. determine the effect of socio-economic characteristics on profitability of poultry production of farmers in selected LGA of Kaduna State.

iv. ascertain the constraints associated with poultry production.

\section{Methodology}

The study was carried out in Kaduna State of Nigeria. The State occupies part of the central position of the Northern part of Nigeria (with Kaduna as its capital) and shares common borders with Zamfara, Katsina, Niger, Kano, Bauchi, Plateau and Nasarawa States. To the southwest, the State shares a border with the Federal Capital Territory, Abuja. The global location of the State is between latitude $90^{\circ}$ and $140^{\circ}$ north of the equator and longitude $70^{\circ}$ and $100^{\circ}$ east of the Greenwich meridian (National Population Commission, 2006). The State occupies an area of approximately $48,473.2$ square kilometres and has a population of more than six (6) million (National Population Commission, 2006), with a population density of 130 people per square kilometre that accounts for $4.3 \%$ of Nigerians total population. The early settlers of Kaduna State were the Atyap (who occupy its southern part) and the Gbari people. Archaeological findings show that Kaduna State was home to the ancient Nok civilization which dates back to 500AD. There are Twenty-Three (23) Local Governments in Kaduna State, which are grouped into Four (4) Agricultural Zones. The Agricultural zones comprises of the Birnin Gwari zone, Maigana Zone, Samaru-Katap zone and the Lere Zone. 


\section{Proceedings of the Annual Conference of the Agricultural Extension Society of Nigeria \\ Number: Twenty-Second Annual Conference \\ Theme: Mainstreaming Entrepreneurship in Agricultural Extension Practice in Nigeria \\ Date: $23^{\text {rd }}-26^{\text {th }}$ April, 2017. Venue: University of Port Harcourt, River State, Nigeria \\ ISSN: 1595 - 1421.http://aesonnigeria.org/ConfProc . Email: editorinchief@aesonnigeria.org}

A Multi-stage sampling technique was used in the study. The first stage was the purposeful selection of one Local Government Area (LGA) from each of the four (4) Agricultural zones in Kaduna State. The selection of these LGA was based on the high number of poultry farmers in each of the four zones through the reconnaissance survey that was conducted. These LGA includes: Sabon-Gari LGA from Maigana Zone, Giwa LGA from Birnin-Gwari Zone, Jema'a LGA from Samaru-Kataf Zone, and Lere LGA from Lere Zone. The second stage involved purposeful selection of two communities with greater number of poultry farmers within the selected LGA and these communities were; Samaru and Zango from Sabon-Gari LGA, Giwa central and Yakawada from Giwa LGA, Angwan Fari and Takau from Kafanchan in Jema'a LGA and Lere town and Saminaka from Lere LGA respectively. In the final stage, twenty (20) poultry farmers were randomly selected from each community to give a total of one hundred and sixty (160) respondents. The data were collected through the use of questionnaire. The data collected include socio economic characteristics of the respondents such as age, marital status, household size, educational level, and income, access to credit, farming experience, and gender. The tools for the data analysis used include descriptive statistics, Gross Margin and Multiple regression analysis.

\section{Results and Discussion}

\section{Socio-Economic Characteristics of Respondents}

Table 1 reveals that the majority $(71.3 \%)$ of the respondents were male and $28.7 \%$ were females. This high proportion of males to females may be because of religion and custom which play crucial roles in the livelihoods of the people in the study area that males are to provide for the household. The implication of male dominance may also be that productivity is expected to be higher because males have tendency to be more labour efficient. Results from the study also revealed that $58.7 \%$ of the respondents were married and $41.3 \%$ were single. This shows that the majority of the respondents were married. This finding is in line with the study by Nurudeen (2012) that the majority of farmers in Kaduna State were married.

Results further revealed that $3.7 \%$ of the respondent were less than 20 years in age, $47.5 \%$ were within the age of $21-30$ years, $22.5 \%$ of the respondents were within the age of $31-40$ years, $17.5 \%$ fell within the age of $41-50,6.3 \%$ were within the age of 51-60 years and $2.5 \%$ were 61 years and above. This shows that the majority of the respondents were within the age bracket of 21-30 years. The implication of this result is that the majority of poultry farmers are within the economic productive age which is in agreement with the findings of Bamiro et al. (2006) who reported that farmers within the age range of 20 - 40 years are in their productive age and they will be able to make fast management decisions as well as take risks in expectation of profit. 
Proceedings of the Annual Conference of the Agricultural Extension Society of Nigeria

Number: Twenty-Second Annual Conference

Theme: Mainstreaming Entrepreneurship in Agricultural Extension Practice in Nigeria

Date: $23^{\text {rd }}-26^{\text {th }}$ April, 2017. Venue: University of Port Harcourt, River State, Nigeria

ISSN: 1595 - 1421.http://aesonnigeria.org/ConfProc . Email: editorinchief@aesonnigeria.org

Table 1: Socio-economic characteristics of respondents

\begin{tabular}{ll}
\hline Variables & Percentage \\
\hline Sex & \\
Male & 71.3 \\
Female & 28.7 \\
Marital status & \\
Married & 58.7 \\
Single & 41.3 \\
Age & \\
$<20$ years & 3.7 \\
$21-30$ & 47.5 \\
$31-40$ & 22.5 \\
$41-50$ & 17.5 \\
$51-60$ & 6.3 \\
61 and above & 2.5 \\
Education qualifications & \\
Primary certificate & 6.3 \\
Secondary certificate & 25.0 \\
Tertiary certificate & 66.3 \\
No formal education & 2.4 \\
Household size & \\
$1-3$ & 17.4 \\
$4-6$ & 46.3 \\
7 and above & 36.3 \\
Years of farming experienced & \\
$1-5$ & 22.4 \\
$6-10$ & 50.0 \\
$11-15$ & 21.3 \\
16 and above & 6.3 \\
Membership of co-operative & \\
Yes & 11.3 \\
Access to credit facility & \\
Yes & 77.5 \\
& \\
\hline & \\
\hline &
\end{tabular}

Results also show that $6.3 \%$ of the respondents had primary education, $25 \%$ had secondary education, $66.3 \%$ had tertiary education and only $2 \%$ had no formal education. This shows that the majority of the respondents were literate with one form of educational qualification or the other. The high literacy level of the respondents would afford them the opportunity to understand and adopt modern farm practices thereby enhancing productivity and profitability. This is in line with the findings of Nurudeen (2012) that the majority of the poultry farmers had tertiary 


\section{Proceedings of the Annual Conference of the Agricultural Extension Society of Nigeria \\ Number: Twenty-Second Annual Conference \\ Theme: Mainstreaming Entrepreneurship in Agricultural Extension Practice in Nigeria \\ Date: $23^{\text {rd }}-26^{\text {th }}$ April, 2017. Venue: University of Port Harcourt, River State, Nigeria \\ ISSN: 1595 - 1421.http://aesonnigeria.org/ConfProc . Email: editorinchief@aesonnigeria.org}

education meaning that they are highly educated. It is expected that the level of education will contribute significantly to decision making of a farmer. It is also in line with the findings by Bukunmi and Yusuf (2015) that level of education had a positive coefficient which could be because education helps the farmers to understand better the innovation introduced to them as regard poultry egg production and also help them to make sound and useful economic and managerial decisions.

The results also show that $17.4 \%$ of the respondents had household size ranging from 1-3, 46.3\% had household size ranging from 4-6 members and $36.3 \%$ had household size of seven (7) members and above. This shows that a majority of the respondents had large household size of 4-6 members which will enhance family labour availability. Since poultry production is labour intensive, the large household size will help in reducing labour constraints in poultry-egg production (Nwaru, 2004). About $22.0 \%$ of the respondents had poultry farming experience between 1-5 years, $50 \%$ had experience between $6-10$ years, $21.3 \%$ had experience between $11-15$ years and $5 \%$ had poultry farming experience of 16 years and above. This shows that respondents had very long years of experience in poultry production, which implies that the respondents are likely to make better decisions to enhance productivity and income, because it is expected that experience in poultry production usually determines the effectiveness of farmers' decision with respect to inputs combinations or resource allocation (Umar, 2012). About $11.0 \%$ of the respondents belong to cooperative association while $88.7 \%$ do not belong to cooperative association. This may be due to the respondents not enjoying the assumed benefits accrued to members of a co-operative of producers' societies through pooling of resources together for a better expansion, efficiency and effective management of resources and for profit maximization. According to Mbanasor (2000), for better development of the livestock industry in Nigeria, the individualistic approach and lack of interaction which hampers the development and optimal utilization of livestock and meat resources should be removed while a cooperative approach should be adopted to enhance performance of the sector. Findings shows that the majority $(77.5 \%)$ of the respondents does not have access to credit facility from banks while $22.5 \%$ of the poultry farmers have access to credit facility. The result of this finding might be as a result of bureaucratic procedure attached in granting credit to farmers from banks.

\section{Profitability of Poultry Farming}

The gross margin analysis from table 2 revealed that the average cost of feed was found to be $\$ 45,569.42$, the average cost for vaccination, $\$ 5$, 230.41; labour, 500.45 with a total variable cost of $85,522.60$. The farmer's average gross income from poultry production was found to be 120,000 . The gross margin was calculated to find the profitability of the enterprise by subtracting the total variable 
Proceedings of the Annual Conference of the Agricultural Extension Society of Nigeria

Number: Twenty-Second Annual Conference

Theme: Mainstreaming Entrepreneurship in Agricultural Extension Practice in Nigeria

Date: $23^{\text {rd }}-26^{\text {th }}$ April, 2017. Venue: University of Port Harcourt, River State, Nigeria

ISSN: 1595 - 1421.http://aesonnigeria.org/ConfProc . Email: editorinchief@aesonnigeria.org

cost from the gross income and was found to be $\$ 34,477.39$. This result shows that poultry farming in the study area was profitable that is for each 885522.60 spent on the enterprise a profit of 34477.39 was realized.

Table 2: Gross margin analysis of poultry farming in the study area

\begin{tabular}{|c|c|}
\hline Variables & Costs ( \\
\hline Cost of feed $\left(x_{1}\right)$ & $45,569.42$ \\
\hline Cost of vaccination $\left(x_{2}\right)$ & $5,230.41$ \\
\hline Cost of labour $\left(\mathrm{x}_{3}\right)$ & $14,500.35$ \\
\hline Cost of chicks $\left(\mathrm{x}_{4}\right)$ & $20,222.45$ \\
\hline $\begin{array}{l}\text { Total variable cost }(T V C)=\left(x_{1}+x_{2}+x_{3}+\right. \\
\left.x_{4}\right)\end{array}$ & $85,522.60$ \\
\hline Gross income (GI) & 120,000 \\
\hline Gross margin & $34,477.39$ \\
\hline
\end{tabular}

\section{Socio-Economic Characteristics Affecting the Profitability of Poultry Farmer's Production}

The result of multiple regression analysis on the socio economic characteristics affecting the profitability of poultry production of poultry farmers in Table 3 shows that the $R^{2}$ was found to be 0.658 which implies that the total variation in the socio economic characteristics affecting the profitability of poultry production to poultry farmers was explained by variation in the independent variables. The result shows that the coefficient of farming experience was positively related to poultry output at $1 \%$ level of significance. This implies that the more the years of experience of the respondents in poultry farming, the more the output that will be realized. It is assumed that continuous practice of an occupation for a long period presumably makes a person more experienced and more productive in practice. This agrees with Adeoti, (2004), who reported that years of experience reduce farmers' inefficiency. 
Proceedings of the Annual Conference of the Agricultural Extension Society of Nigeria

Number: Twenty-Second Annual Conference

Theme: Mainstreaming Entrepreneurship in Agricultural Extension Practice in Nigeria

Date: $23^{\text {rd }}-26^{\text {th }}$ April, 2017. Venue: University of Port Harcourt, River State, Nigeria

ISSN: 1595 - 1421.http://aesonnigeria.org/ConfProc . Email: editorinchief@aesonnigeria.org

Table 3: Socio-economic characteristics affecting profitability of poultry farmer's production

\begin{tabular}{llll}
\hline Variables & Coefficient & Std. Err. & T-value \\
\hline Constant & 0.623 & 0.823 & 0.769 \\
Sex & 0.146 & 0.505 & 0.288 \\
Marital status & 2.583 & 3.096 & 0.834 \\
Farming experience & 0.018 & 0.006 & $2.985^{\star \star \star}$ \\
Education qualification & 0.007 & 0.009 & -0.078 \\
Access to credit & 0.363 & 0.103 & $3.536^{* \star \star}$ \\
Household size & -0.341 & 0.119 & $-1.871^{*}$ \\
Membership of cooperative & -0.023 & 0.042 & -0.562 \\
$\mathrm{R}^{2}=0.658$ & & & \\
$\mathrm{R}^{2}$ adjusted $=0.586$ & & & \\
\hline${ }^{* \star *} \mathrm{P} \leq 0.01^{*} \mathrm{P} \leq .0 .10$ & & &
\end{tabular}

The coefficient of household size negatively affected output of poultry farmers at $10 \%$ level of significance. This implies that the more the household members the lower the output, this may be as a result of less supply of labour or non-active participation by the younger members of the households because youths of modern days prefer white-collar jobs. The negative coefficient is against a priori expectations and findings of Damisa et al. (2007).

The study also revealed that, the coefficient of the respondents' access to credit is positively related to output of poultry in the study area at $5 \%$ level of significance. This implies that the more the farmer has access to credit the more his output. This is because availability of credits helps to finance the purchase of feed, purchase of more birds and expansion of farm land which will in turn increase the output level. Similar result had been reported by Ajibefun and Aderinola (2003).

\section{Constraints Associated with Poultry Production}

Table 4 reveals that the three most critical constraints facing poultry farmers in the study area were high cost of feeds (92.5\%), lack of access to credit facilities (82.5\%) and incidence of diseases $(80.0 \%)$. Other constraints include: high mortality rate birds $(71.8 \%)$; high cost of vaccines (63.7\%) and poor marketing outlets for the birds $(61.3 \%)$. 
Proceedings of the Annual Conference of the Agricultural Extension Society of Nigeria

Number: Twenty-Second Annual Conference

Theme: Mainstreaming Entrepreneurship in Agricultural Extension Practice in Nigeria

Date: $23^{\text {rd }}-26^{\text {th }}$ April, 2017. Venue: University of Port Harcourt, River State, Nigeria

ISSN: 1595 - 1421.http://aesonnigeria.org/ConfProc . Email: editorinchief@aesonnigeria.org

Table 4: Distribution of the respondents on constraints faced in poultry production

Constraints

High cost of feed

Lack of credit

Incidence of diseases

High mortality

High cost of vaccines

Poor marketing outlets
Percentage

\section{5}

82.5

80.0

71.8

63.7

61.3

*Multiple responses

\section{Conclusion and Recommendations}

Based on the information obtained from this study, it was concluded that poultry venture was found to be profitable in the study area. Household size, farming experience and the farmer's access to credit facility are the factors affecting profitability of poultry production. To reduce high cost of inputs, government should subsidize the inputs to poultry farmers. Also, farmers should be encouraged to form co-operative society to enable them pull their resources together and help themselves.

\section{Reference}

Abubakar, H. (2000). Economic Analysis of Egg Production in Birnin Gwari, Jama'a and Igabi Local Government Area of Kaduna State. Ahmadu Bello University, Zaria, Nigeria: M.S.C Dissertation Department of Agricultural Economics and Rural Sociology.

Adeoti, A. I. (2004). Impact of HIV/Aids and Related Sickness on the Technical Efficiencies

of Farmers in Benue State, Nigeria. Issues in African Rural Development Monograph Series

Agbato, O. A. (1997). Effective Strategies for Egg Marketing in Nigeria. Paper Presented at a workshop organized by the Nigeriia Society for Animal Production (NSAP). Ogun State, Nigeria

Ajibefun, I. A., \& Daramola, A. G. (2003). Determinants of technical and allocative 


\section{Proceedings of the Annual Conference of the Agricultural Extension Society of}

Nigeria

Number: Twenty-Second Annual Conference

Theme: Mainstreaming Entrepreneurship in Agricultural Extension Practice in Nigeria

Date: $23^{\text {rd }}-26^{\text {th }}$ April, 2017. Venue: University of Port Harcourt, River State, Nigeria

ISSN: 1595 - 1421.http://aesonnigeria.org/ConfProc . Email: editorinchief@aesonnigeria.org

efficiencies of micro-enterprises: Firm- level evidence from Nigeria. Bulletin of African Development Bank, 4, 353-395.

Akeeb, S. (1997). Problems of Poultry Production in Nigeria. Paper Presented at Workshop

organized by the Nigeria Society for Animal Production (NSAP) . Ogun State, Nigeria.

Bamiro, O. M., Philip, D. O., \& Momoh, S. O. (2006). Vertical Integration and Production

Efficiency in Poultry (Egg) Industry in Ogun and Oyo States. Nigeria. International Journal of Poultry Science (2), 1164-1171.

Bukunmi, F. R., \& Yusuf, H. A. (2015). Analysis of Socio-Economic Factors Influencing

Poultry Egg Production among Poultry Farmers in Ondo State, Nigeria. British Journal of Applied Scienec and Technology, 10 (3), 1-7.

Damisa, M. A., Samndi, J. R., \& Yohanna, M. (2007). Women Participation in Agricultural Production: A probit analysis. Journal of Applied Sciences, 7 (3), 412-414.

Food and Agriculture Organization (FAO) (2007). Poultry in the 21st Century: Avian Influenza and Beyond. (eds) Proceedings of the International Poultry Conference, held 5-7th November 2007. Bangkok, ThailandFAOSTAT (2009), Food Security Statistics.

Food and Agriculture Organisation. (FAO), (2014). The State of World Fisheries and Aquaculture 2006. Rome, FAO: 162pp

Food and Agriculture Organisation (FAO), (2009). The state of Food and Agriculture. Livestock in the Balance. FAO, Rome

Jane M.C., Odo, E., Asadu, A.N. and Enwelu, I.A. (2012). Poultry farmers' adaptation to

climate change in Enugu North Agricultural Zone of Enugu State, Nigeria. In Proceedings of 17 th Annual Conference of Agricultural Extension Society of Nigeria (AESON), Held at University of Nigeria, Nsuka, Enugu State. $11^{\text {th }}-14^{\text {th }}$, March, 2012.pp 246-259.

Kazybayeva, S., Otte, J., \& Roland-Holst, D. (2006). "Livestock production and Household

Income Patterns in Rural Senegal". Pro-Poor Livestock Policy Facility Food and Agriculture Organization- Animal Production and Health Division Viale delle Terme di Caracalla Rome, Italy

Mbanasor, J. A. (2000). The Future of Livestock Industry in Nigeria. In: Ukachukwu, S.N.;

Ibeauchi, J.A.; Ibe, S.N.; Ezekwe .G. and Abasiekong. S.F. (eds), Animal Production in the New Millennium: Challenges and Options. Book of Proceedings of 25th Annual Conference Umudike, 19-23 March, (p. 397).

Nation Bureau of Statistics (NBS) (2012). Federal Ministry of Agriculture and Rural

Development, Collaborative Survey on National Agriculture Sample Survey (NASS), 2010/2011, Draft Report, May, 2012. 
Proceedings of the Annual Conference of the Agricultural Extension Society of Nigeria

Number: Twenty-Second Annual Conference

Theme: Mainstreaming Entrepreneurship in Agricultural Extension Practice in Nigeria

Date: $23^{\text {rd }}-26^{\text {th }}$ April, 2017. Venue: University of Port Harcourt, River State, Nigeria

ISSN: 1595 - 1421.http://aesonnigeria.org/ConfProc . Email: editorinchief@aesonnigeria.org

National Population Commission (NPC) (2006).Federal Republic of Nigeria, 2006 Population

Census. National Population Commission, www.nigerianstat.gov.ng

Nouala, S., Pica-Ciamarra, U., Otte, J., \& N'guetta, A. (2011). Investing inn Livestock to Drive Economic Growth in Africa. Rationales and Priorities .

Nurudeen, J. A. (2012). Economics and social characteristics of registered poultry egg producers in Ilorin, Kwara State. Russian Journal of Agricultural and Socio-Economic Sciences, 11 (11).

Nwaru, J. C. (2004). Rural Credit Market and Arable Crop Production in Imo State of Nigeria. Phd Dissertation, Micheal Okpara University of Agriculture, Umudike.

Nworgu, F. C. (2002). Economics of utilization of cocoa ( Theobroma cocao) pod husk meal by cockerel chicks. Moor J. Agric. Res , 3 (2), 217-222.

Okoli, I. C., Anyaegbunam, C. N., Etuk, E. B., Uchegbu, M. C., \& Udedibie, A. B. (2004). Socio Economic Characteristics of Poultry Business Entrepreneurs in Imo State, Nigeria. Journal of Agriculture and Social Research, 4 (2).

Okonkwo, W. I., \& Akubuo, C. O. (2001). Thermal Analysis and Evaluation of Heat Requirement of a Passive Solar Energy Poultry Chick Brooder in Nigeria. Journal of renewal energy, 9 (1), 37-39.

Oyesola, O. B., \& Olujide, M. G. (2000). Participation of Livestock Farmers in Nigeria, Insurance scheme. A case study of Iseyin L.G.A. Proceedings of Animal Scienec Association of Nigeria Conference, Port Harcout sept. 19-22, (p. 213).

Rotschild, J. (2002). Nigeria Poultry and Products Poultry Update. Grain Report \#N12025

Umar, M. (2012). Economic Analysis of Poultry Egg Production in Bauchi Local Government Area, Nigeria. A thesis submitted to the school of postgraduate studies, Ahmadu Bello University Zaria, Kaduna State, Nigeria. 